\title{
Erratum to: Perceived health is partially associated with the symptomatological profile in patients with benign and severe conditions: the case of congenital heart disease
}

\author{
D. Schoormans • M. A. G. Sprangers • \\ W. Budts · B. J. M. Mulder $\cdot$ S. Apers • \\ P. Moons
}

Published online: 23 October 2012

(C) Springer Science+Business Media Dordrecht 2012

\section{Erratum to: Qual Life Res \\ DOI 10.1007/s11136-012-0241-4}

Unfortunately, the reference list and corresponding text numbers as included in the original publication contain several errors. These errors are listed below, and the correct numbers correspond with the entries in the list of References at the end of this erratum.

Another error in the original publication is the asterisk included in Table 2, which should have been removed.

The online version of the original article can be found under doi:10.1007/s11136-012-0241-4.

D. Schoormans $(\square)$. B. J. M. Mulder

Department of Cardiology, Academic Medical Center,

Meibergdreef 15, 1105 AZ Amsterdam, The Netherlands

e-mail: d.schoormans@amc.uva.nl

D. Schoormans - M. A. G. Sprangers

Department of Medical Psychology, Academic Medical Center,

Amsterdam, The Netherlands

D. Schoormans · B. J. M. Mulder

Interuniversity Cardiology, Institute of the Netherlands,

Utrecht, The Netherlands

W. Budts $\cdot$ P. Moons

Division of Congenital and Structural Cardiology,

University Hospitals Leuven, Leuven, Belgium

\section{S. Apers $\cdot$ P. Moons}

Center for Health Services and Nursing Research,

Catholic University of Leuven, Leuven, Belgium

P. Moons

The Heart Centre, Copenhagen University Hospitals,

Copenhagen, Denmark
THE CORRECTIONS ONLY CONCERN THE NUMBERS; NOT THE TEXT!

- Page 2: right column: line 17 "used similar methods $[15,16]$ " should be "used similar methods $[14,17]$ "

- Page 2: right column: line 26 "inclusion in this study [15]" should be "inclusion in this study [14]"

- Page 2: right column: line 30 "foramen ovale [15]" should be "foramen ovale [14]"

- Page 2: right column: line 40 "registry for patients with CHD [17]" should be "registry for patient with CHD [18]"

- Page 2: right column: line 42 "or illiterate in Dutch [16]" should be "or illiterate in Dutch [17]"

- Page 3: left column: line 4 "[18]" should be "[19]"

- Page 3: left column: line 5 "(NYHA) classification [19]" should be "(NYHA) classification [20]"

- Page 3: left column: line 12 "of the ACC [18]" should be "of the ACC [19]"

- Page 3: left column: line 14 "NYHA classification [19]" should be "NYHA classification [21]"

- Page 3: left column: line 21 "in both patient samples [20]" should be "in both patient samples [22]"

- Page 3: left column: line 29 "TAAQOL-CHD algorithm [20]" should be TAAQOL-CHD algorithm [22]"

- Page 3: left column: line 52 "CHD [15]" should be "CHD [14]"

- Page 3: right column: line 4 "EVGFP rating [21]" should be "EVGFP rating [23]"

- Page 6: right column: last line "the most distressing ones [22, 23]" should be "the most distressing ones [24, 25]"

- Page 7: left column: last line "(the gold standard) [24]" should be "(the gold standard) [26]"

- Page 8: left column: [24] should be [26]

- Page 8: right column: [25, 26] should be [27, 28]

- Page 8: right column: [16, 27] should be [16, 29]

- Page 8: right column: [28-30] should be [30-32] 


\section{References}

14. Moons, P., van Deyk, K., de Geest, S., Gewillig, M., \& Budts, W. (2005). Is the severity of congenital heart disease associated with the quality of life and perceived health of adult patients? Heart, 91(9), 1193-1198.

15. Moons, P., van Deyk, K., \& de Bleser, L., et al. (2006). Quality of life and health status in adults with congenital heart disease: A direct comparison with healthy counterparts. European Journal of Cardiovascular Prevention and Rehabilitation, 13(3), 407-413.

16. Riley, J. P., Habibi, H., Banya, W., Gatzoulis, M. A., LauWalker, M., \& Cowie, M. R. (2011). Education and support needs of the older adult with congenital heart disease. Journal of Advanced Nursing. doi:10.1111/j.1365-2648.2011.05809.x.

17. Schoormans, D., Sprangers, M. A., \& Pieper, P. G., et al. (2011). The perspective of patients with congenital heart disease: Does health care meet their needs? Congenit Heart Dis, 6(3), 219-227.

18. Van der Velde, E. T., Vriend, J. W., Mannens, M. M., Uiterwaal, C. S., Brand, R., \& Mulder, B. J. (2005). CONCOR, an initiative towards a national registry and DNA-bank of patients with congenital heart disease in the Netherlands: rationale, design, and first results. European Journal of Epidemiology, 20(6), 549-557.

19. Warnes, C. A., Liberthson, R., \& Danielson, G. K., et al. (2001). Task force 1: The changing profile of congenital heart disease in adult life. Journal of the American College of Cardiology, 37(5), $1170-1175$.

20. The Criteria Committee of the New York Heart Association. (1973). Disease of the heart and blood vessels: nomenclature and criteria for diagnosis (7th ed.). Boston: Little Brown.

21. Schoormans, D., Mager, Y. L., Oort, F. J., Sprangers, M. A., \& Mulder, B. J. (2012). New York Heart Association class assessment by cardiologists and outpatients with congenital cardiac disease: A head-to-head comparison of three patientbased versions. Cardiology in the Young, 22(1), 26-33.

22. Kamphuis, M., Zwinderman, K. H., \& Vogels, T., et al. (2004). A cardiac-specific health-related quality of life module for young adults with congenital heart disease: Development and validation. Quality of Life Research, 13(4), 735-745.
23. Ware, J. E, Jr, \& Sherbourne, C. D. (1992). The MOS 36-item short-form health survey (SF-36). I. Conceptual framework and item selection. Medical Care, 30(6), 473-483.

24. Moons, P., de Geest, S., Abraham, I., Cleemput, J. V., \& van Vanhaecke, J. (1998). Symptom experience associated with maintenance immunosuppression after heart transplantation: Patients' appraisal of side effects. Heart and Lung, 27(5), 315-325.

25. Larsen, J., Nordstrom, G., Bjorkstrand, B., Ljungman, P., \& Gardulf, A. (2003). Symptom distress, functional status and health-related quality of life before high-dose chemotherapy with stem-cell transplantation. European Journal of Cancer Care (England), 12(1), 71-80.

26. Anderson, R. B., \& Testa, M. A. (1994). Symptom distress checklists as a component of quality of life measurement: comparing promted reports by patient and physician with concurrent adverse event reports via the physician. Drug Information Journal, 28(1), 89-114.

27. Simko, L. C., \& McGinnis, K. A. (2003). Quality of life experienced by adults with congenital heart disease. AACN Clin Issues, 14(1), 42-53.

28. Kovacs, A. H., Saidi, A. S., \& Kuhl, E. A., et al. (2009). Depression and anxiety in adult congenital heart disease: Predictors and prevalence. International Journal of Cardiology, 137(2), 158-164.

29. Schoormans, D., Mulder, B. J., \& van Melle, J. P. et al. (2012). Patients with a congenital heart defect and Type D personality feel functionally more impaired, report a poorer health status and quality of life, but use less healthcare. European Journal of Cardiovascular Nursing. doi:10.1177/1474515112437828.

30. Howren, M. B., \& Suls, J. (2011). The symptom perception hypothesis revised: Depression and anxiety play different roles in concurrent and retrospective physical symptom reporting. Journal of Personality and Social Psychology, 100(1), 182-195.

31. Petersen, S., van den Berg, R. A., Janssens, T., \& van den Bergh, O. (2011). Illness and symptom perception: A theoretical approach towards an integrative measurement model. Clinical Psychology Review, 31(3), 428-439.

32. Williams, L., O’Connor, R. C., Grubb, N. R., \& O'Carroll, R. E. (2011). Type D personality and illness perceptions in myocardial infarction patients. Journal of Psychosomatic Research, 70(2), 141-144. 